\title{
PENGARUH BEBERAPA FITOHORMON PADA PEMBENTUKAN MUTAN BARLEY (Hordeum Vulgare) DENGAN FENOTIP BIJI ABNORMAL
}

\author{
Ira N. Djajanegara \\ *) PT Bioindustri - BPPT \\ Email: idjajanegara@yahoo.com
}

\begin{abstract}
Seg8 is the shrunken endosperm mutant occured naturally in barley (Hordeum vulgare). This recessive mutant does not express xenia which indicates that the endosperm phenotypes depend on the genotype of the diploid maternal parents. This mutant provides an opportunity to analyze factors produced by the female parent that affect the seed development process. One of the factors affecting seed development and growth is phytohormones. In vitro spike culture culture system adopted from wheat spike culture system was used to investigate the involvement of phytohormones in the grain filling process. Phytohormones were applied during 15 days period

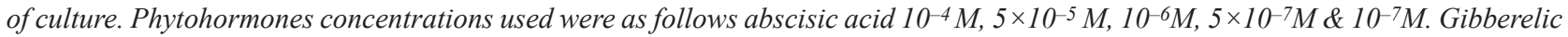
acid concentrations were $5 \times 10^{-3} \mathrm{M}, 5 \times 10^{-4} \mathrm{M}, 5 \times 10^{-5} \mathrm{M}, 2.5 \times 10^{-5} \mathrm{M}, 10^{-5} \mathrm{M} \& 2 \times 10^{-6} \mathrm{M}$. Cytokinin concentrations were $2 \times 10^{-6} \mathrm{M}$, $2 \times 10^{-7} \mathrm{M} \& 2 \times 10^{-8} \mathrm{M}$. In this experiment, 2 days before anthesis is the best stage to start the spike culture period and 15 days period of culture is sufficient to observe the grain filling process \& emergence of the mutant phenotype. The phytohormones treatments as well as their respective concenrations were not able to recover the normal phenotype. Abscisic acid treatment at $5 \times 10^{-7} M$ were able to increase the mutant grain dry weight significantly compared to untreated culture but the normal phenotype was not recovered. This indicates that lack of phytohormones was not the maternal factor affecting the seed development process in this particular mutant.
\end{abstract}

Key words: mutation, barley (Hordeum vulgare), phytohormones, spike culture

\section{PENGANTAR}

Ketidakmampuan untuk mengatur suplai dan komposisi asimilat dari bagian lain tanaman ke biji mempersulit kajian tentang jumlah dan komposisi asimilat yang optimum untuk pertumbuhan biji. Akan tetapi metode kultur malai yang dilakukan oleh Donovan dan Lee (1977) pada tanaman gandum (Triticum aestivum) dapat diadopsi untuk mengatasi permasalahan ini. Dalam sistem kultur malai ini, tangkai malai ditumbuhkan di media cair selama 12 hari mengalami proses pengisian biji yang normal dicerminkan dengan berat biji, kandungan karbohidrat dan protein seperti pada kondisi in-vivo (Donovan dan Lee, 1977). Dengan demikian sistem kultur malai ini dapat digunakan untuk mempelajari pengaruh fitohormon terhadap pertumbuhan biji seperti yang disarankan oleh Duffus (1985). Karena hampir semua fitohormon yang terlibat dalam proses pengisian biji diimpor dari bagian lain tanaman maka sistem ini dapat dipakai untuk mengatur jumlah fitohormon yang tesedia dengan memblokir mekanisme impor normal. Sitokinin (Van Staden, 1983) dan asam absisik (ABA) (Brenner et al., 1982) tidak disintesis di biji melainkan diimpor dari bagian lain dari tanaman. Demikian pula dengan asam giberelik (GA) (Khan, 1982).

Fitohormon telah ditengarai oleh beberapa peneliti berperan dalam proses pengisian biji (Khan, 1982; Duffus, 1985). Menurut Bewley dan Black (1985), fitohormon berperan dalam proses pertumbuhan dan perkembangan biji, akumulasi cadangan makanan (karbohidrat, protein, dll.) dalam biji dan efek-efek fisiologis pada jaringan-jaringan dan organ-organ di dekat biji. Aktivitas sitokinin pada biji Lupinus albus meningkat sejalan dengan bertambahnya volume endosperm yang mengindikasikan keterlibatannya. Pada tanaman-tanaman monokotil aktivitas sitokinin tertinggi pada saat endosperm dalam fase susu atau fase cairan. Sitokinin berperan dalam pembelahan sel dan sintesis protein dengan merangsang mitosis dan autolisis tRNA. Adanya ciri khas dalam penurunan kandungan GA selama proses pematangan biji pada beberapa tanaman biji-bijian termasuk barley (Bewley dan Black, 1985) menguatkan dugaan peranan fitohormon ini dalam proses pengisian biji. ABA telah lama diduga terlibat dalam proses transport asimilat karena aplikasi fithormon ini ke biji yang sedang tumbuh meningkatkan impor asimilat (Bewley dan Black, 1985). Ho et al. (1982) membuktikan bahwa buah tomat yang letaknya lebih jauh dari batang mempunyai ukuran buah yang lebih besar dan kandungan ABA yang lebih rendah daripada yang letaknya lebih dekat dari batang.

Mutan alami, resesif dan berbiji kecil segl-seg8 ditemukan pada tanaman barley (Hordeum vulgare) varietas Klages dalam proses pemuliaan tanaman. Mutan-mutan ini tidak mengekspresikan xenia yang mengindikasikan bahwa 
fenotip mutan-mutan tersebut ditentukan oleh genotip induk betina. Berdasarkan studi mikroskopis, mutan seg1, seg3, seg6 dan seg7 mengalami kematian (nekrosis) dini pada sel-sel pembentuk jaringan chalaza dan nuclear projection sehingga proses pengisian biji terhambat yang berakibat didapatnya ukuran biji yang lebih kecil. Jaringan chalaza dan nuclear projection adalah jaringan induk betina yang terhubung ke biji. Keempat mutan lainnya, yaitu seg2, seg4, seg5 dan seg8 tidak menunjukkan abnormalitas pada jaringan-jaringan yang terlibat dalam proses pengisian biji walaupun biji dari keempat tanaman barley mutan tersebut lebih kecil dibanding pasangan normalnya (Felker et. al., 1985). Tidak adanya abnormalitas pada jaringan transpor asimilat yang teramati pada mutan-mutan ini terutama mutan seg8 menunjukkan bahwa jalur impor faktor pemicu mutasi dari jaringan induk tidak terganggu sehingga kemungkinan yang tersisa adalah kekurangan faktor tertentu atau sebaliknya adanya faktor tertentu dari induk betina yang menyebabkan terjadinya mutasi. Salah satu kandidat faktor penentu tersebut adalah fitohormon.

Dalam rangka membuktikan adanya keterlibatan fitohormon dalam munculnya fenotip mutan berbiji kecil pada seg8, maka diadopsi sistem kultur malai dari tanaman gandum. Aplikasi sistem ini dengan konsentrasi fitohormon yang berbeda-beda diharapkan dapat menjawab pertanyaan di atas. Jika kekurangan fitohormon tertentu atau keberadaan fitohormon tertentu dalam jumlah suboptimal maka pemberian fitohormon tersebut dalam sistem kultur malai seg 8 secara teoretis dapat menghilangkan fenotip biji kecil yang diderita mutan tersebut.

\section{BAHAN DAN CARA KERJA}

\section{Bahan Tanaman}

Biji barley mutan seg8 dan varietas Klages ditanam secara bersamaan di rumah kaca dengan pemberian nutrisi seperti yang dilakukan oleh Peterson dan Schrader (1974). Pemotongan malai tanaman barley mutan seg8 maupun kontrol varietas Klages dilakukan pada 2 hari sebelum anthesis sesuai penelitian sebelumnya (Djarot dan Peterson, 1991).

\section{Kultur Malai Barley (Hordeum vulgare)}

Berdasarkan penelitian pendahuluan maka kultur malai dapat dilakukan pada 2 hari sesudah anthesis yang ditandai dengan munculnya ujung daun bendera secara penuh. Malai $3 \mathrm{~cm}$ dipotong di bawah buku batang dan daun bendera dibuang. Batang malai disterilisasi permukaan dengan $0,525 \%(\mathrm{w} / \mathrm{v}) \mathrm{NaOCl}$, lalu dibilas beberapa kali dengan $d d \mathrm{H}_{2} \mathrm{O}$ sebelum dipotong ulang sehingga kurang lebih $2 \mathrm{~cm}$ di bawah buku dalam media cair untuk menghindari adanya gelembung udara dalam pembuluh xylem. Semua transfer dilakukan dalam kondisi aseptis (Donovan dan Lee, 1977). Kultur malai ditumbuhkan pada $100 \mathrm{ml}$ media cair yang diwadahi tabung Erlenmeyer $125 \mathrm{ml}$ ditumbuhkan pada inkubator dengan suhu $18 \pm 2^{\circ} \mathrm{C}$ dengan 16 jam cahaya dari lampu halida logam selama 15 hari. Kultur malai mutan (seg8) dan normal (varietas Klages) ditumbuhkan bersama-sama dengan kontrol (baik mutan maupun normal) yang ditumbuhkan pada pot dalam inkubator yang sama. Penambahan fitohormon hanya dilakukan pada media yang dipakai untuk menumbuhkan mutan seg 8 sedangkan media kultur malai seg8 sebagai kontrol tidak ditambahkan fitohormon.

Media kultur mengandung sukrosa, garam-garam inorganik, vitamin dan asam amino seperti yang digambarkan oleh Trione dan Stockwell (1989). Dengan penambahan $\mathrm{KOH}$ atau asam asetat maka $\mathrm{pH}$ media dibuat menjadi 5,6 dan disterilisasikan dengan filter Millipore ukuran $0,22 \mu \mathrm{m}$.

Pemanenan biji dilakukan pada 5, 10, dan 15 hari dalam periode kultur untuk pengamatan pertumbuhan biji dan 15 hari untuk pengamatan perlakuan fitohormon.

\section{Perlakuan Fitohormon}

Fitohormon diberikan selama 15 hari periode kultur. Konsentrasi ABA yang ditambahkan pada media adalah $5 \times 10^{-5} \mathrm{M}, 10^{-5} \mathrm{M}, 10^{-6} \mathrm{M}, 5 \times 10^{-7} \mathrm{M}$ dan $10^{-7} \mathrm{M}$. Adapun konsentrasi GA yang dipakai pada penelitian ini adalah $5 \times 10^{-3} \mathrm{M}, 5 \times 10^{-4} \mathrm{M}, 5 \times 10^{-5} \mathrm{M}, 2.5 \times 10^{-5} \mathrm{M}, 10^{-5} \mathrm{M}$ dan $2 \times 10^{-6} \mathrm{M}$. Sedangkan konsentrasi sitokinin (kinetin) yang ditambahkan pada media kultur malai mutan seg 8 adalah $2 \times 10^{-6} \mathrm{M}, 2 \times 10^{-7} \mathrm{M}$ dan $2 \times 10^{-8} \mathrm{M}$.

\section{Metode Analisis}

Pertumbuhan biji diukur dalam bentuk peningkatan berat kering biji. Pada penelitian pendahuluan adopsi kultur malai gandum dilakukan dengan 3 ulangan untuk kedua genotip yang diamati, yaitu varietas Kalges dan mutan seg8. Sedangkan untuk perlakuan fitohormon dipakai 4 ulangan. Lima biji dari masing-masing malai yang ditumbuhkan secara in-vitro dipanen untuk diukur berat keringnya. Data yang terkumpul diuji secara statistik dengan ANOVA (analysis of variance) pada tingkat kemungkinan 0,05. Perbedaan signifikan yang terkecil (LSD) antara kedua genotip dihitung menggunakan standard error yang tepat. Untuk menganalisis perbedaan antara kontrol dan perlakuan fitohormon digunakan student's t-test. 


\section{HASIL}

Data penambahan berat kering biji yang ditumbuhkan dengan sistem kultur malai pada varietas Klages dan mutan seg8 ditunjukkan pada Gambar 1. Data-data tersebut mengindikasikan bahwa baik mutan seg8 maupun varietas Klages mampu melanjutkan proses pengisian bijinya pada laju yang tidak berbeda nyata dibandingkan kontrol yang ditumbuhkan pada pot. Menurut Donovan dan Lee (1977), biji gandum yang ditumbuhkan dengan sistem kultur malai dapat tumbuh setara dengan yang ditumbuhkan di lapang.

Data pada Gambar 1 menunjukkan bahwa berat kering akhir biji pada 15 hari kultur dari varietas Klages yang ditumbuhkan secara in-vitro sedikit lebih rendah daripada yang ditumbuhkan secara in-vivo. Akan tetapi perbedaan ini tidaklah nyata secara statistik. Di sisi lain, berat kering akhir biji mutan seg8 yang ditumbuhkan pada 15 hari periode kultur sedikit lebih tinggi dibanding yang ditumbuhkan secara in-vivo walaupun secara statistik tidak nyata (Gambar 1). Data pada Gambar 1 juga menunjukkan bahwa fenotip mutasi yang dicerminkan oleh berat kering biji menjadi tampak nyata secara statistik pada 8 hari sesudah anthesis atau 10 hari dalam periode kultur malai. Hasil pengamatan mikroskopis pada potongan melintang biji kedua genotip tersebut memperlihatkan bahwa pada periode 11 hari dalam kultur perbedaan keduanya tampak sangat nyata (Gambar 2). Penelitian sebelumnya membuktikan bahwa fenotip mutan mulai dapat diamati pada periode 8 hari sesudah anthesis (Djarot dan Peterson, 1991).

Data pengaruh pemberian fitohormon ditunjukkan oleh Tabel 1. Perlakuan sitokinin (kinetin) pada konsentrasi $2 \times 10^{-6} \mathrm{M}, 2 \times 10^{-7} \mathrm{M}$ dan $2 \times 10^{-8} \mathrm{M}$ tidak memberikan peningkatan berat biji yang signifikan terhadap kontrol baik dalam berat kering maupun berat basah. Kontrol dalam hal ini adalah seg8 yang ditumbuhkan tanpa perlakuan fitohormon. Perlakuan konsentrasi sitokinin

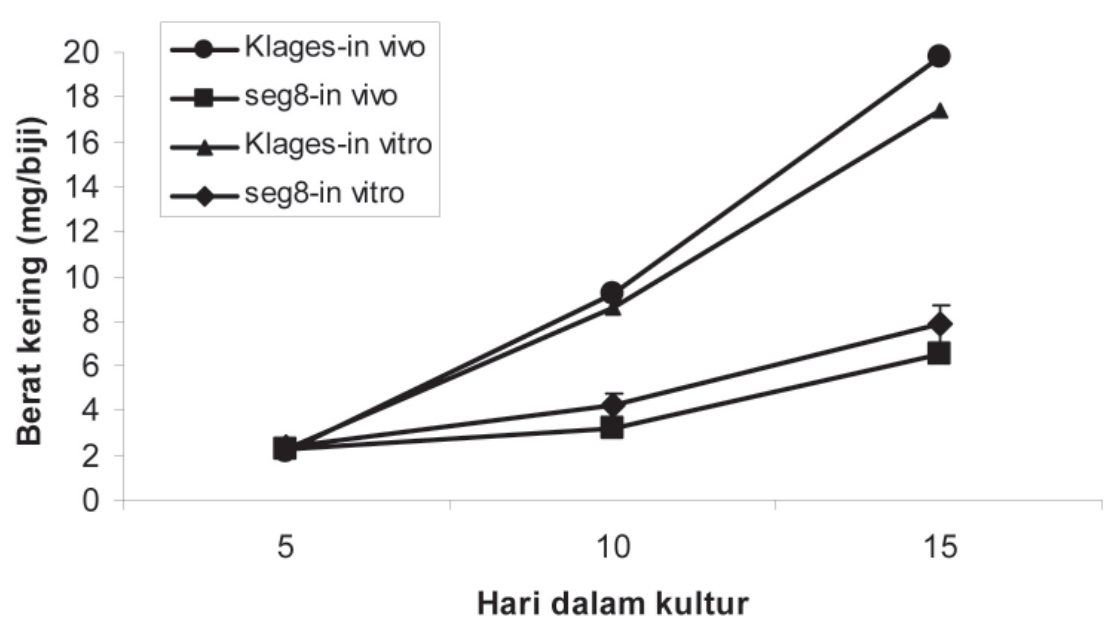

Gambar 1. Berat kering biji mutan seg8 dan varietas Klages dalam sistem kultur malai yang dimulai 2 hari sebelum anthesis selama 15 hari. Garis menunjukkan LSD antara perlakuan pada $P=0.05$. Data adalah rerata dari 5 biji yang dipanen dari 3 botol kultur yang berbeda
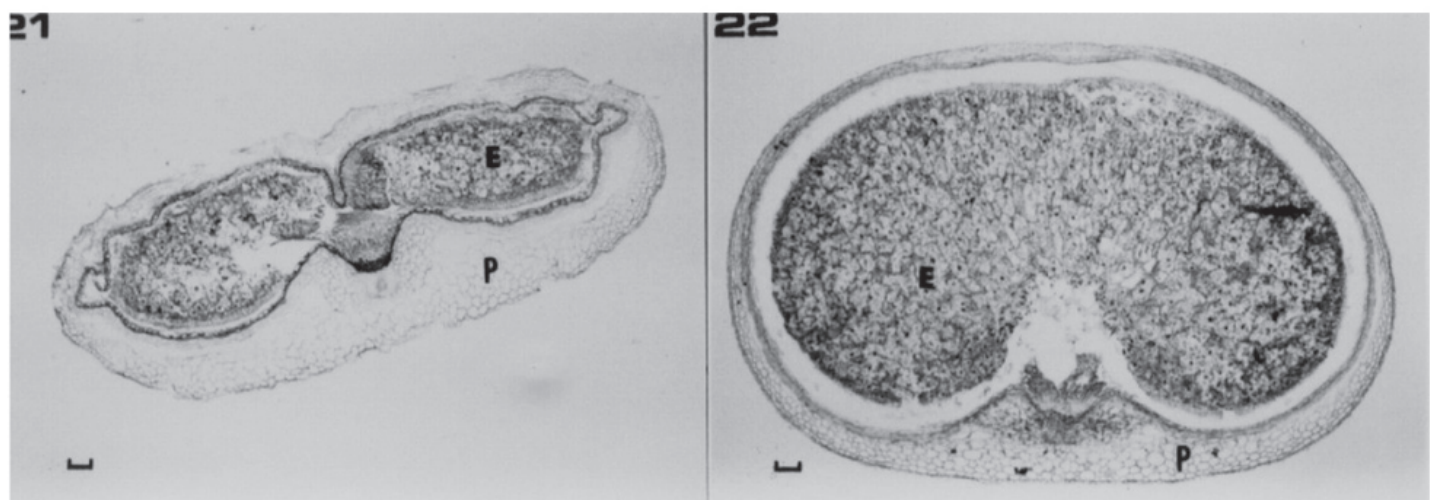

Gambar 2. Potongan melintang biji barley seg 8 (kiri) dan varietas Klages (kanan) pada 11 hari dalam kultur malai 
tidak menunjukkan dampak yang nyata dalam penelitian ini (Tabel 1) sehingga dapat disimpulkan bahwa sitokinin bukanlah faktor penentu mutasi pada seg8.

Konsentrasi asam absisik (ABA) yang dipakai dalam penelitian ini adalah $5 \times 10^{-5} \mathrm{M}, 10^{-5} \mathrm{M}, 10^{-6} \mathrm{M}, 5 \times 10^{-7}$ $\mathrm{M}$ dan $10^{-7} \mathrm{M}$ pada penelitian pertama terlihat tendensi peningkatan berat biji sejalan dengan penurunan konsentrasi ABA (Tabel 1). Berdasarkan hasil yang didapat pada penelitan pertama ini, maka dilakukan penelitian kedua dengan menurunkan konsentrasi asam absisik (ABA) untuk melihat adanya pengaruh yang lebih signifikan dalam

Tabel 1. Berat basah dan berat kering biji barley mutan seg8 dan varietas Klages yang dipanen pada 15 hari dalam kultur malai dengan dan tanpa perlakuan fitohormon

\begin{tabular}{lll}
\hline \multirow{2}{*}{$\begin{array}{l}\text { Jenis fitohormon/ } \\
\text { konsentrasi }\end{array}$} & \multicolumn{2}{c}{ Berat basah $\quad$ Berat kering } \\
\cline { 2 - 3 } & -------------- mg --------- \\
\hline
\end{tabular}

Penelitian pertama:

Kontrol

24,8

9,3

Sitokinin:

$\begin{array}{lll}2 \times 10-6 \mathrm{M} & 23,9 \mathrm{a} & 8,8 \mathrm{a} \\ 2 \times 10-7 \mathrm{M} & 23,1 \mathrm{a} & 8,5 \mathrm{a} \\ 2 \times 10-8 \mathrm{M} & 23,8 \mathrm{a} & 9,4 \mathrm{a}\end{array}$

GA:

$5 \times 10-5 \mathrm{M}$

$26,7 a$

$2,5 \times 10-5 \mathrm{M}$

$26,3 a$

10-5 M

$2 \times 10-6 \mathrm{M}$

$24,4 a$

$25,3 a$

ABA:

10-4 M

$5 \times 10-5 \mathrm{M}$

10-5 M

$23,2 a$

$25,4 a$

$27,6 a$

$30,9 b$

24,4

9,1

Kontrol

GA:

\begin{tabular}{llr}
$5 \times 10-3 \mathrm{M}$ & $15,0 \mathrm{~b}$ & $6,1 \mathrm{~b}$ \\
$5 \times 10-4 \mathrm{M}$ & $25,1 \mathrm{a}$ & $10,1 \mathrm{a}$ \\
$5 \times 10-5 \mathrm{M}$ & $25,7 \mathrm{a}$ & $10,0 \mathrm{a}$ \\
ABA: & & \\
$10-6 \mathrm{M}$ & $27,0 \mathrm{~b}$ & $10,2 \mathrm{~b}$ \\
$5 \times 10-7 \mathrm{M}$ & $28,7 \mathrm{~b}$ & $10,4 \mathrm{~b}$ \\
$10-7 \mathrm{M}$ & $28,4 \mathrm{~b}$ & $10,4 \mathrm{~b}$ \\
\hline
\end{tabular}

Keterangan: a) tidak berbeda nyata antara kontrol dan perlakuan berdasarkan t-test $(P>0,05)$

b) berbeda nyata $(P<0,05)$ proses pengisian biji pada mutan seg 8 sehingga diharapkan dapat merehabilitasi fenotip biji kecil pada mutan ini. Pada penelitian kedua terlihat bahwa berat biji basah maupun kering maksimum dicapai pada konsentrasi $5 \times 10^{-7} \mathrm{M}$ dan penurunan konsentrasi lebih jauh hingga $10^{-7} \mathrm{M}$ tidak menyebabkan peningkatan berat biji lebih lanjut.

Untuk memastikan apakah fenotip mutan, yang berupa adanya lekukan pada bagian dorsal biji, telah direhabilitasi maka dilakukan pengamatan potongan melintang pada biji barley mutan seg 8 yang ditumbuhkan secara in-vitro (Gambar 3). Biji tersebut diambil dari malai yang dikulturkan selama 15 hari dengan penambahan asam absisik (ABA) sebesar $5 \times 10^{-7} \mathrm{M}$. Dara berat kering sebelumnya menunjukkan adanya peningkatan berat biji yang secara statistik signifikan dengan penambahan asam absisik (ABA) sebesar $5 \times 10^{-7} \mathrm{M}$ (Tabel 1) dibandingkan kontrol varietas Klages yang juga ditumbuhkan secara in-vitro. Data pada Gambar 3 tidak menunjukkan adanya rehabilitasi pada fenotip mutan tersebut sehingga dapat disimpulkan asam absisik bukanlah faktor penyebab mutasi. Adapun kenaikan berat kering biji akibat asam absisik (ABA) lebih disebabkan karena mekanisme transpor asimilat yang dipicu lebih efisien.

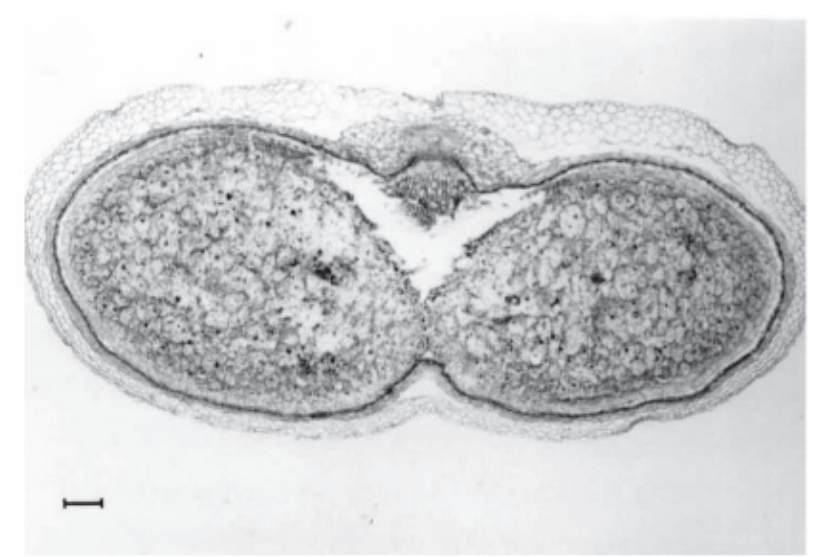

Gambar 3. potongan melintang dari biji mutan seg8 dengan perlakuan $5 \times 10^{-7} \mathrm{M}$ ABA selama 15 hari dalam kultur malai

Keterangan: skala garis $=0,2 \mathrm{~mm}$

\section{PEMBAHASAN}

Penelitian pendahuluan menunjukkan bahwa 2 hari sesudah anthesis adalah saat yang tepat untuk memulai kultur malai. Periode ini juga sejalan dengan tujuan penelitian ini karena 2 hari sesudah anthesis adalah cukup awal untuk merekayasa asimilat yang akan masuk ke dalam biji sebelum fenotip mutasi muncul. Periode ini juga memungkinkan untuk mendapatkan cukup waktu dalam mengamati pemunculan fenotip mutasi secara bertahap 
selama 15 hari kultur. Bedasarkan penelitian sebelumya, fenotip mutasi dapat terdeteksi pada potongan melintang biji sejak 8 hari sesudah anthesis (Djarot dan Peterson, 1991).

Data yang didapat pada gambar 1 mengindikasikan bahwa proses pengisian biji pada mutan seg 8 tidak berbeda nyata dengan varietas Klages di mana malai kedua genotip ini ditumbuhkan secara in-vitro selama periode 15 hari. Setelah 15 hari terlihat proses pengisian biji baik pada mutan seg8 maupun varietas Klages mengalami stagnasi atau tidak terlihat adanya pertambahan berat biji (data tidak diperlihatkan). Menurut Donovan dan Lee (1977), biji gandum yang ditumbuhkan dengan sistem kultur malai dapat tumbuh setara dengan yang ditumbuhkan di lapang. Hal ini dicerminkan oleh berat biji, kandungan nitrogen, kandungan karbohidrat dan protein yang tidak berbeda nyata selama 15 hari periode dalam kultur. Trione dan Stockwell (1989) menambahkan bahwa perkembangan malai secara in-vitro tidak berbeda dengan in-vivo dalam hal pembentukan serbuk sari, kepala putik dan viabilitas embrionya.

Data pada Gambar 1 menunjukkan bahwa berat kering akhir biji pada 15 hari kultur dari varietas Klages yang ditumbuhkan secara in-vitro sedikit lebih rendah daripada yang ditumbuhkan secara in-vivo. Akan tetapi perbedaan ini tidaklah nyata secara statistik. Di sisi lain, berat kering akhir biji mutan seg 8 yang ditumbuhkan pada 15 hari periode kultur sedikit lebih tinggi dibanding yang ditumbuhkan secara in-vivo walaupun secara statistik tidak nyata. Hal yang sama terjadi pada mutan seg 8 dan varietas Klages yang ditumbuhkan secara in-vivo. Menurut Ramage dan Crandall (1981), perbedaan lingkungan tidak memengaruhi fenotip biji abnormal pada mutan seg8. Kesemuanya menunjukkan bahwa sistem kultur malai dapat dipakai untuk mengamati pengaruh fitohormon dalam terekspresinya fenotip mutasi.

Data pengaruh pemberian fitohormon ditunjukkan oleh Tabel 1. Perlakuan sitokinin (kinetin) pada konsentrasi $2 \times 10^{-6} \mathrm{M}, 2 \times 10^{-7} \mathrm{M}$ dan $2 \times 10^{-8} \mathrm{M}$ tidak memberikan peningkatan berat biji yang signifikan terhadap kontrol baik dalam berat kering maupun berat basah. Menurut Radley (1978), salah satu alasan kurangnya respons terhadap perlakuan fitohormon adalah ketidakmampuan dari sistem aplikasi untuk mengantarkan fitohormon ke jaringan target atau organ target. Proporsi relatif dari kombinasi beberapa fitohormon dapat juga menjadi faktor kurangnya respons tersebut. Dalam penelitian ini, ada kemungkinan terjadinya degradasi atau modifikasi dari fitohormon yang diberikan ke dalam media kultur malai. Menurut Duffus (1985), fitohormon dapat mengalami perubahan konsentrasi dan modifikasi karena transpor juga melalui sistem vaskular yang berisi cairan xilem atau ploem. Kemungkinan lain adalah mutasi memengaruhi sensitivitas dari reseptor sitokinin yang kemungkinan terletak pada jaringan yang berasal dari induk betina seperti, misalnya chalaza, dan lain-lain. Dalam hal ini maka faktor penentu mutasi bukanlah fitohormon melainkan reseptor dari fitohormon atau produk hasil interaksi antara reseptor dan fitohormon seperti yang dikemukakan oleh Felker et al. (1987). Konsentrasi fitohormon tidak relevan jika reseptornya tidak ada (Trewavas, 1981).

Konsentrasi asam giberelik (GA) yang dipakai dalam penelitian ini adalah $5 \times 10^{-3} \mathrm{M}, 5 \times 10^{-4} \mathrm{M}, 5 \times 10^{-5} \mathrm{M}$, $2,5 \times 10^{-5} \mathrm{M}, 10^{-5} \mathrm{M}$ dan $2 \times 10^{-6} \mathrm{M}$. Pada penelitian yang pertama terlihat adanya tendensi peningkatan berat biji sejalan dengan meningkatnya konsentrasi GA walaupun secara statisik tidak nyata (Tabel 1). Untuk lebih mempertegas, maka dilakukan penelitian kedua di mana konsentrasi GA ditinggikan. Akan tetapi tidak ada peningkatan yang nyata yang diperlihatkan oleh data berat basah maupun berat kering biji. Bahkan pada konsentrasi GA yang tertinggi, yaitu $5 \times 10^{-3} \mathrm{M}$, terlihat adanya penurunan berat biji secara signifikan yang mengindikasikan bahwa pemberian GA yang terlalu berlebihan malahan menyebabkan penurunan berat biji. Beberapa fitohormon, antara lain auksin, dilaporkan sebagai herbisida pada konsentrasi yang tinggi. (Salisbury dan Ross, 1985).

Pemberian asam absisik (ABA) pada penelitian pertama menunjukkan adanya tendensi meningkatnya berat biji sejalan dengan menurunnya konsentrasi asam absisik (Tabel 1). Akan tetapi, pada penelitian kedua (Tabel 1) berat biji tidak mengalami peningkatan lagi dengan diturunkannya konsentrasi sitokinin. Berat maksimum biji mutan seg8 dicapai pada konsentrasi asam absisik (ABA) sebesar $5 \times 10^{-7} \mathrm{M}$. Asam absisik (ABA) dilaporkan mempunyai peranan penting dalam transpor dan penyimpanan asimilat selama pertumbuhan biji. ABA memicu pergerakan asimilat ke dalam biji barley yang sedang tumbuh membesar (Tietz et al., 1981). Hasil yang sama juga dilaporkan pada biji gandum (Dwedney dan McWha, 1978), buah anggur (Hale dan Combe, 1974; During dan Alleweldt, 1980) dan biji kedelai (Clifford et al., 1986). Peningkatan berat biji mutan seg8 yang signifikan dengan pemberian ABA sebesar $5 \times 10^{-7} \mathrm{M}$ kemungkinan besar adalah akibat pemicuan proses akumulasi asimilat ke dalam biji tanpa melenyapkan fenotip mutasi. Kesimpulan ini harus dibuktikan dengan penelitian-penelitian selanjutnya.

Sistem kultur malai dari biji gandum yang diterapkan pada barley merupakan sistem yang cocok untuk mengetahui pengaruh fitohormon dalam terekspresinya fenotip mutasi 
pada mutan barley seg8. Kultur malai secara in-vitro dalam periode 15 hari yang dimulai pada saat biji berusia 2 hari sesudah anthesis mampu menunjukkan proses pengisian biji yang tidak berbeda dengan kondisi in-vivo. Pemberian sitokinin dan asam giberelik (GA) tidak memberikan pengaruh yang nyata dalam upaya mengembalikan fenotip mutan menjadi normal. Perlakuan asam absisik (ABA) pada konsentrasi $5 \times 10^{-7} \mathrm{M}$ mampu meningkatkan berat biji secara signifikan melalui pemicuan penimbunan asimilat ke dalam biji yang sedang tumbuh akan tetapi fenotip mutan tidak dapat dipulihkan menjadi normal.

\section{KEPUSTAKAAN}

Bewley DJ dan Black M, 1985. Seed physiology and germination. Plenum Press, New York.

Brenner ML, Hein MB, Schussler J, Dale J, dan Brun A, 1982. Coordinate control: The involvement of abscissic acid, it's transport and metabolism. In Wareing PF (ed.). Plant Growth Substances. Academic Press, New york. pp. 343-52.

Clifford PE, Offler CE, dan Patrick JW, 1986. Growth regulators have rapid effects on photosynthate unloading from seed coats of Phaseoulus vulgaris L. Plant Physiol. 80: 635-7.

Djarot IN dan Peterson DM, 1991. Seed development in a shrunken endosperm barley mutant. Ann. of Bot. 68: 495-9.

Dwedney SJ and McWha A, 1978. The metabolism and transport of abscissic acid during grain filling in wheat. J. Exp. Bot. 29: 1299-308.

Donovan GR dan Lee JW, 1977. The growth of detached wheat heads in liquid culture. Plant Sci. Lett. 9: 107-13.

Duffus CM, 1985. Plant growth regulators and cereal grain development and germination. In Brights SWJ dan Jones MGK (ed.). Cereal tissue and cell culture. Martinus Nijhoff/Dr W. Junk Publisher, Dodrecht/Boston/Lancaster. pp. 97-126.
During H dan Alleweldt G, 1980. Effects of plant hormones on phloem transport in grapevines. Ber. Deutsch. Bot. Ges. 93: 339-47.

Felker FC, Peterson DM, dan Nelson OE, 1985. Anatomy of immature grains of eight maternal effect shrunken endosperm barley mutants. Amer. J. Bot. 72: 248-256.

Felker FC, Peterson DM, dan Nelson OE, 1987. Early grain development of seg2 maternal effect shrunken endosperm muant of barley. Can. J. Bot. 65: 943-8.

Hale, CR dan Coombe BG, 1974. Abscisic acid - an effect on the ripening of grapes. In: RL Bieleski et al. (eds.). Mechanisms of regulation of plant growth. Bull. R. Soc. N. Z. 12: 831-836.

Ho LC, Sjut V, dan Hoad GV, 1982. The effect of assimilate supply on fruit growth and hormone levels in tomato plants. Plant Growth Regulation 1: 155-71.

Khan AA, 1982. The physiology and biochemistry of seed development, dormancy and germination. Elsevier Biomedical Press, Amsterdam-New York-Oxford. pp. $158-81$.

Radley M, 1978. Factors affecting grain enlargement in wheat. J. Exp. Bot. 33: 717-28.

Ramage RT dan Crandall CR, 1981. Shrunken endosperm mutant seg8. Barley Genet. Newsl. 11: 34.

Salisbury F dan Ross C, 1985. Plant Physiology $3^{\text {rd }}$ ed. Wadsworth Publisher, London. 432-457.

Tietz A, Ludewig M, Dingkuhn M, dan Dorffling K, 1981. Effect of abscisic acid on the transport of assimilates in barley. Planta 152: 557-61.

Trewavas A, 1981. How do plant growth substances work? Plant Cell Environ. 4: 203-220.

Trione EJ dan Stockwell VO, 1989. Development of detached wheat spikelets in culture. Plant Cell, Tissue and organ Culture 17: 161-70.

Van Staden, J. 1983. Seeds and cytokinins. Physiol. Plant. 58: 340-346.

Reviewer: Prof. Dr. Santosa 